\title{
Optimisation of Electrical Distribution System by Using Solar Thermal Powered Systems and Its Impact on Electrical Distribution Feeders
}

\author{
Punnaiah Veeraboina1, G. Yesuratnam² \\ ${ }^{1}$ Department of Electrical Engineering, Centre for DNA Fingerprinting and Diagnostics (CDFD), Hyderabad, India \\ ${ }^{2}$ Department of Electrical Engineering, Osmania University, Hyderabad, India \\ Email:v_m2004@hotmail.com, ratnamgy2003@yahoo.co.in
}

Received 11 February 2016; accepted 26 April 2016; published 29 April 2016

Copyright @ 2016 by authors and Scientific Research Publishing Inc.

This work is licensed under the Creative Commons Attribution International License (CC BY).

http://creativecommons.org/licenses/by/4.0/

\section{(c) (i) Open Access}

\begin{abstract}
In this research, the performance of the solar thermal powered systems (STPS) is analyzed with different models (without inserts, with inserts and with Nano fluids with different concentrations) and its impact on the Electric load in a residential/Institutional Electrical Distribution system. For this purpose, the electrical and solar thermal water heater is tested and validated. Solar thermal powered systems and its impact on the Institutional electrical distribution feeders are tested and compared with the energy efficiency (EE) and cost optimization. The goal of this paper is to analyze the impact of solar thermal energy on electrical energy consumption in the electrical distribution feeder level. The electrical system cost and energy consumptions are tabulated and observed that there is a considerable savings.
\end{abstract}

\section{Keywords}

Solar Thermal Power Systems, Electrical Distribution Feeder, Energy Consumption, Automatic Power Factor Correction, Electrical Heaters

\section{Introduction}

As the cost of energy continues to rise and research budgets grow ever tighter, lab's autoclave is an excellent place to create savings without compromising on usability or results. Autoclaves kill different pathogens by subjecting the equipment and tools to steam $121^{\circ} \mathrm{C}$ for 30 minutes. Institutional electrical water heating is con- 
sidered the second most energy-intensive activity which accounts for approximately 15\% of a home's energy consumption, after HVAC [1]. This fraction could be as high as 30\% for residents in winter dominated parts of the world [2]. Solar thermal water heating systems which utilize solar energy to produce hot water can be easily retrofitted into existing electric/gas water heating systems. Solar domestic hot water systems have been widely adopted since they use solar radiation which is free of cost, despite the changes that need to be incorporated to existing systems - such as installation of solar collectors, preheat tanks, internal or external heat exchangers, and circulation control and piping systems [3] [4]. B. S. Swanson and J. H. Fletcher [5] investigate the effects of solar thermal water heaters (includes the integral collector storage and active drain-back open loop systems) on peak demand.

Generally, a residential electric water heater with a tank for hot water storage is set to heat water at the outlet to a setting point of value $\mathrm{T}_{\text {set, }}$, with a $\mathrm{T}_{\text {delta }}$ dead band [6] [7]. As soon as hot water is drawn, an equal amount of cold water replenishes the tank at the same flow rate. When the mixed water temperature at the outlet drops below the lower bound, i.e. $\mathrm{T}_{\text {tank }}<\mathrm{T}_{\text {set }}+\mathrm{T}_{\text {delta }}$, the heating elements are turned on to work at rated power till the outlet hot water temperature attains the set point value, i.e. $\mathrm{T}_{\mathrm{set}}+\mathrm{T}_{\text {delta. }}$. Water heaters with storage tanks are not free of the standby loss, unlike the tank less water heaters. The heating elements are turned off unless the outlet temperature is not within the range of the dead band, i.e. $\mathrm{T}_{\text {set }}-\mathrm{T}_{\text {delta }} \leq \mathrm{T}_{\text {tank }} \leq \mathrm{T}_{\text {set }}+\mathrm{T}_{\text {delta }}$.

Solar water heating systems are in high demand. Typically, 30\% - 40\% of a family's electricity bill is devoted to devoted water. Sun Heat's system can save the individual family from $70 \%$ to $90 \%$ of the total amount spent on the Electricity used for heating water. The system generally meets all of the summer time heating needs. During times of decreased sunlight, the system will preheat the water then bring it up to temperature by the conventional water heating system already in place.

For the flat plate collectors, glass panes play an important role in auxiliary electric energy consumption. Flat plate collectors with two glass panes save about 10\% - 15\% auxiliary electrical energy compared to those with no glass panes and about 3\% - 5\% energy saving compared to collectors with one glass pane. This is because there are reduced wind convective losses with glass panes. However, there are also transmittance losses from glass panes and there are upper limits on how many glass panes can be used.

The present research is focused on optimization of electrical distribution system (i.e., to reduce the electrical materials used in the system) by using the enhanced solar water heating system (SWHS) and its impact on the electrical distribution feeders. The main purpose is to reduce the Electrical energy consumption and system ratings (i.e., transformer size, cable sizes, MCB's and feeder sizes).

\section{Autoclaves}

Autoclaving is one of the techniques used in moist heat sterilisation. All R\&D organisations and other hospitals requiring their tools to be sterilized need autoclaves. Inlet water to the Autoclaves is normal raw water which is having a temperature between $20^{\circ} \mathrm{C}-26^{\circ} \mathrm{C}$ depending upon the season. The operational temperature for the Autoclave is $121^{\circ} \mathrm{C}$. There is huge gap between the inlet temperature to the Autoclaves and required for operation. By using the different technics, the experiments are carryout on the Solar flat plate collectors with different models (with inserts, without inserts \& by using Nano-fluids) to enhance the output temperature at $90^{\circ} \mathrm{C}$. Considerable energy is saved in this system by using solar heated water than the conventional Electrical water heaters. The savings are not only the Electrical Energy savings but also the savings on the SITC (Supply, Installation, Testing and Commissioning) of Electrical Installations (Electrical Distribution System). The principle behind the working of an Autoclave is that-The higher the pressure created inside the autoclave, the higher would be the attainable temperature inside it.

The boiling point of water at normal atmospheric pressure is $100^{\circ} \mathrm{C}$. when the free-flowing steam at a temperature of $100^{\circ} \mathrm{C}$ is subjected under pressure of 1 atmosphere above the sea-level pressure i.e., $15 \mathrm{lbs}$ pressure per sq. inch, the temperature inside the autoclave happens to rise up to $121^{\circ} \mathrm{C}$, which is an usual and common parameters employed in the moist heat sterilisation.

Steam enters the chamber jacket, passes through an operating valve and enters the rear of the chamber behind a baffle plate. It flows forward and down through the chamber and the load, exiting at the front bottom. A pressure regulator maintains jacket and chamber pressure at a minimum of $15 \mathrm{psi}$, the pressure required for steam to reach $121^{\circ} \mathrm{C}$. Overpressure protection is provided by a safety valve. The average American home would take 45 years to consume that much energy. This extreme example serves as a reminder of how resource-intensive high- 
volume, high-throughput medical-grade autoclaves can be.

\subsection{Mode of Action/Principle of Moist Heat Sterilization}

Moist heat destroys microorganisms by the irreversible denaturation of enzymes and structural proteins. The temperature at which denaturation occurs varies inversely with the amount of water present. Sterilization in saturated steam thus requires precise control of time, temperature, and pressure.

Pressure serves as a means to obtain the high temperatures necessary to quickly kill microorganisms. Specific temperatures must be obtained to ensure the microbicidal activity. Minimum sterilization time should be measured from the moment when all the materials to be sterilized have reached the required temperature throughout.

Most of the manufactures recommends the sterilization process in an autoclave are $15 \mathrm{~min}$. at $121^{\circ} \mathrm{C}$ and pressure at $2 \mathrm{~atm}$. Table 1 represents the different combinations of temperature, pressure and time. Control and monitor the process is purely based on the temperature and pressure settings to obtain the required steam temperature.

Sterilization may be carried out some time even below at $121^{\circ} \mathrm{C}$ shown in Figure 1, it's mostly depends upon the pressure and temperature during the sterilisation.

Steam held at elevated temperature and pressure for time is used to transfer moist heat. Steam has much greater heat transfer than boiling water, -80 calories to boil water, 540 calories to produce steam. Heat acts to denature proteins, effectively killing all cells present.

The steam of the autoclave shown above has been provided from a solar flat plate collector which was stored in a thermal storage system. The required temperature for the Autoclave system is $121^{\circ} \mathrm{C}$. Normally the solar water heating system is designed for $60^{\circ} \mathrm{C}$. But by using the different technics (with inserts and with Nano-fluids) the temperature of the solar flat plat collector is enhanced from $60^{\circ} \mathrm{C}-90^{\circ} \mathrm{C}$.

Hospitals, R\&D labs and other regional health centres can greatly benefit from using solar Autoclaves. Rural Primary Health Clinics where Electricity is not available to generate steam could benefit from solar Autoclaves.

\subsection{Impact on Solar thermal Autoclaves on Electrical Distribution Load}

Impact on Solar thermal Autoclaves on Electrical Distribution Load in Institutional Building @60 ${ }^{\circ} \mathrm{C}$ and its cost analysis at $500 \mathrm{kVA}$ level is shown in Table 2.

Table 1. Different combinations of temperature, pressure and time.

\begin{tabular}{cccc}
\hline S No. & Temperature in ${ }^{\circ} \mathrm{C}$ & $\begin{array}{c}\text { Approx. corresponding } \\
\text { pressure (atm) }\end{array}$ & $\begin{array}{c}\text { Mini. sterilization } \\
\text { time (minutes) }\end{array}$ \\
\hline 1 & $126-129$ & 2.50 & 10 \\
2 & $129-134$ & 2.75 & 7.5 \\
3 & $134-138$ & 3.0 & 5 \\
\hline
\end{tabular}

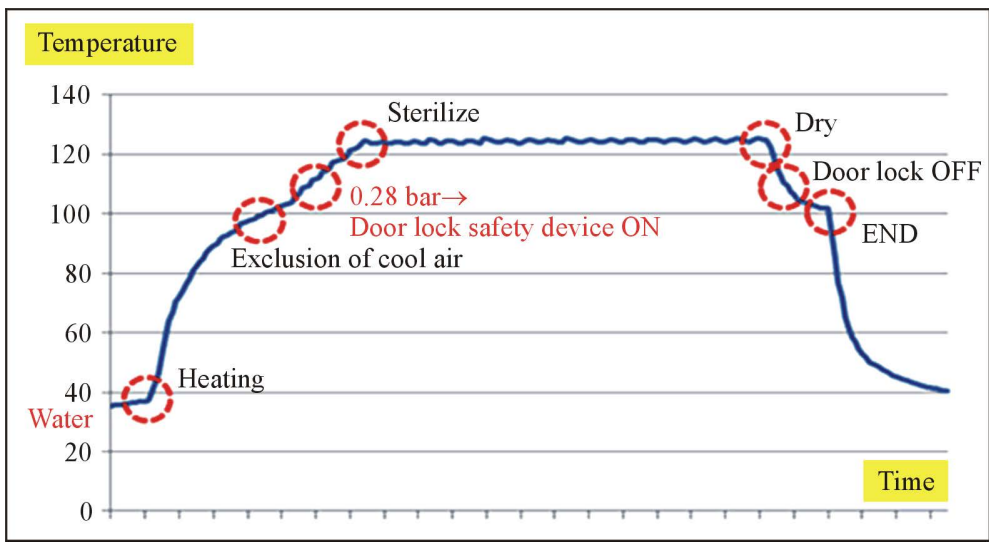

Figure 1. Time vs temperature graph for sterilisation. 
Table 2. Electrical load and the cost analysis of solar autoclaves.

\begin{tabular}{|c|c|c|c|c|c|c|c|}
\hline Description & No of heaters & $\mathrm{kW}$ & Units/day & $\begin{array}{l}\text { No. of units/ } \\
\text { month }\end{array}$ & Unit rate (Rs) & $\begin{array}{c}\text { Expenditure/ } \\
\text { month (Rs) }\end{array}$ & $\begin{array}{l}\text { Expenditure/ } \\
\text { annum (Rs) }\end{array}$ \\
\hline $\begin{array}{l}\text { Autoclaves on } \\
\text { electric heaters }\end{array}$ & $\begin{array}{c}04 \times 2 \text { systems } \\
(8 \text { Nos })\end{array}$ & $\begin{array}{l}18 \mathrm{~kW} \times 04 \times \\
02=144 \mathrm{~kW}\end{array}$ & $\begin{array}{c}432(72 \mathrm{~kW} \text { for } \\
30 \text { Min } \times 6 \\
\text { loads } \times 2 \text { systems }\end{array}$ & $\begin{array}{c}8640 \text { (20 day } \\
\text { month) }\end{array}$ & 7.00 & 60,480 & 725,760 \\
\hline $\begin{array}{l}\text { Autoclaves on } \\
\text { electric heaters }\end{array}$ & $\begin{array}{l}04 \times 1 \text { system } \\
\quad(4 \text { Nos })\end{array}$ & $\begin{array}{c}18 \mathrm{~kW} \times 04 \times \\
01=72 \mathrm{~kW}\end{array}$ & $\begin{array}{c}216(72 \mathrm{~kW} \text { for } \\
30 \text { Min } \times 6 \\
\text { loads } \times 01 \text { systems }\end{array}$ & $\begin{array}{c}4320 \text { (20 day } \\
\text { month) }\end{array}$ & 7.00 & 30,240 & 362,880 \\
\hline $\begin{array}{c}\text { Autoclaves on } \\
\text { SWHS }\end{array}$ & Nil & Nil & $\begin{array}{l}08 \text { flat plate } \\
\text { collectors }\end{array}$ & Nil & Nil & Nil & Nil \\
\hline
\end{tabular}

Capacity of the Autoclave is $72 \mathrm{~kW}$. Each Electrical Element is $18 \mathrm{~kW}$.

Number of Electrical elements is 04 Nos.

So, total capacity of the Autoclave is $18 \mathrm{~kW} \times 04$ Nos $=72 \mathrm{~kW}$.

Electrical Power Consumption/day:

$18 \mathrm{~kW} \times 04$ Nos $\times 30 \mathrm{~min}(0.5 \mathrm{Hrs})=36 \mathrm{kWh}$.

Daily number of loads is 06 times, Number of Autoclaves is 02 Nos.

So, the total Electrical Energy consumption/day $=36 \mathrm{~kW} \times 06$ Nors $\times 02$ systems $=432 \mathrm{kWh}$.

Number of units per month:

Normally R\&D labs will work only 05 day week, so, the number days per month $=20$ days.

Number of units consumed per month $=432 \mathrm{kWh} \times 20$ days $=8640$ units.

As per Cat-II tariff, per unit charge is Rs 7 per unit.

So, the Electrical Power consumption per year is 8640 units $\times$ Rs $7=$ Rs 60,480.

Electrical Power Consumption per year:

Rs 60,480 × 12 Months = Rs 725,760.

Figure 2 represents the SLD (Single Line Diagram) and Bill of Materials (BoQ) of 500 kVA Electrical Distribution system at feeder level.

Designed capacity of the Electrical Distribution system is $500 \mathrm{kVA}$ :

Without using the solar water heating system, the required temperature of the Autoclaves is around $121^{\circ} \mathrm{C}$. To increase the temperature at $121^{\circ} \mathrm{C}, 144 \mathrm{~kW}(18 \mathrm{~kW} \times 8 \mathrm{Nos})$ of Electrical Heaters are used. The capacity of the Electrical Load is $144 \mathrm{~kW}$ at 0.98 P.F (say $150 \mathrm{kVA}$ ).

The Electrical Distribution system, one of the feeder (250 Amps, TPN MCCB-Power Load) is connected to the domestic water heating load, the total Electrical load of 40 rooms of each $2.5 \mathrm{~kW}$ capacity Electrical heaters are connected.

There for the total capacity of the domestic heating Electrical load $=2.5 \mathrm{~kW} \times 40$ rooms $=100 \mathrm{~kW}=102$ $\mathrm{kVA}(100 \mathrm{~kW}$ at $0.98 \mathrm{P} . \mathrm{F})$. The load reduction is $150 \mathrm{kVA}+102 \mathrm{kVA}=252 \mathrm{kVA}$, the other Distribution loads are $248 \mathrm{kVA}$.

Based on the above Electrical loads the recommended size of Transformer is $500 \mathrm{kVA}$ and its cost analysis is shown in Table 3.

\subsection{Automatic Power Factor Correction (With Thyristor Switched)}

Techniques can be applied to the industries, power systems and also households to make them stable and due to that the system becomes stable and efficiency of the system as well as the apparatus increases. The use of microcontroller reduces the costs. Automatic Power factor correction (APFC) device reads the power factor from line voltage and line current, calculating the compensation requirement switch on different banks. Improving the power factor of an installation requires a bank of capacitors which acts as a source of reactive energy. This arrangement is said to provide reactive energy compensation.

An inductive load having a low power factor requires the generators and transmission/distribution systems to pass reactive current with associated power losses and exaggerated voltage drops. If a bank of shunt capacitors is added to the load, its (capacitive) reactive current will take the same path through the power system as that of the load reactive current. Since, as pointed out, this capacitive current Ic is in direct phase opposition to the load 


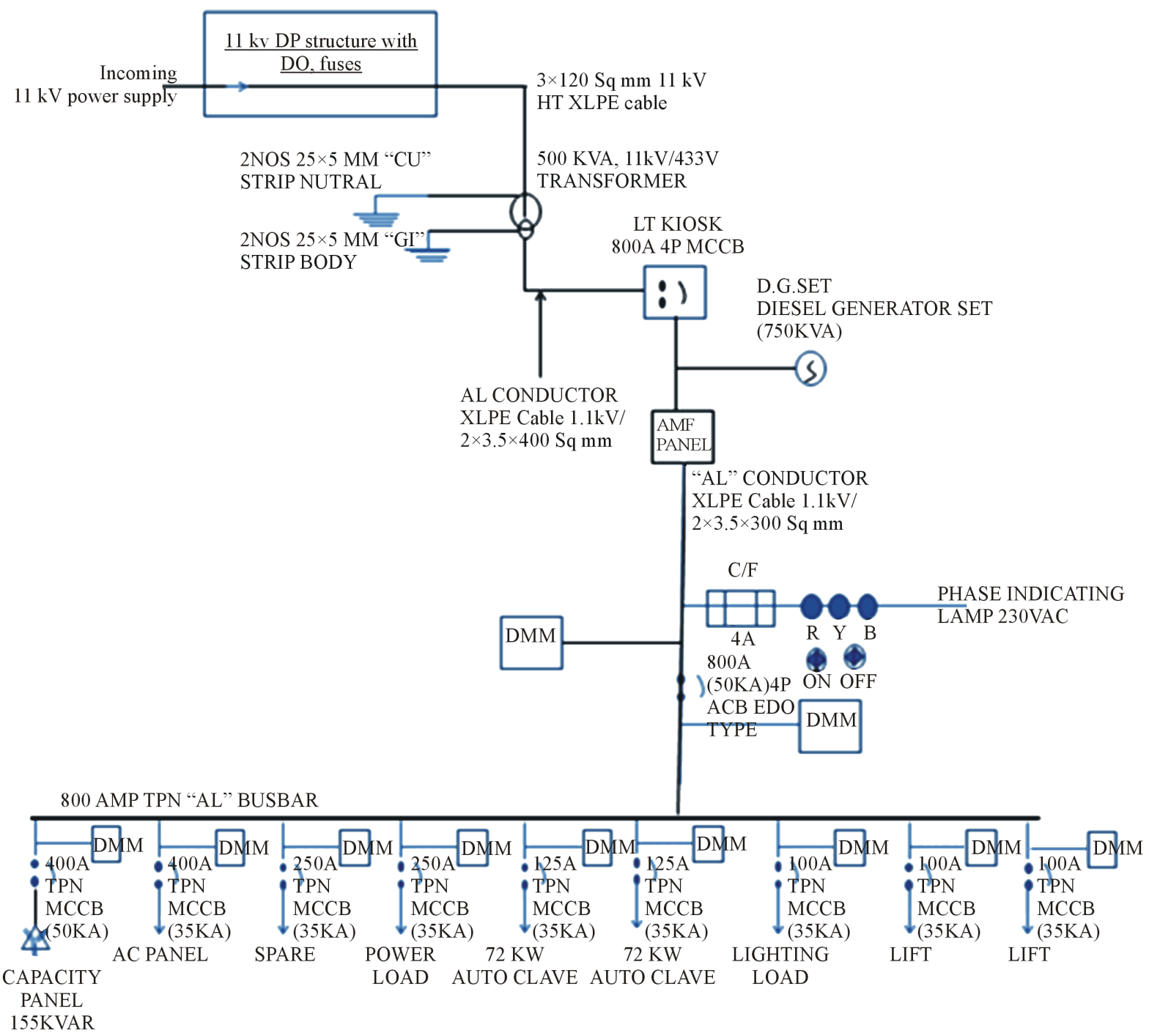

Figure 2. Single line diagram of the electrical distribution system for $500 \mathrm{kVA}$ transformer level.

Table 3. Cost analysis of Electrical Distribution systems at $500 \mathrm{kVA}$ Transformer level.

\begin{tabular}{|c|c|c|c|c|c|}
\hline S No. & Description & Qty & UoM & Rate (Rs) & Total system cost (Rs) \\
\hline 1 & $\begin{array}{c}\text { HT cable: supply of } 11 \mathrm{kV} 3 \mathrm{C} \times 120 \text { Sq. mm HT } \\
\text { XLPE armoured Cable. }\end{array}$ & 50 & Mtr & 1100 & 55,000 \\
\hline 2 & $\begin{array}{l}\text { LT cables: supply of } 3.5 \mathrm{c} \times 400 \text { Sq. mm XLPE insulated, } \\
1.1 \mathrm{kV} \text { grade armoured aluminium cable. }\end{array}$ & 100 & Mtr & 1800 & 180,000 \\
\hline 3 & HT metering panel $(11 \mathrm{kV})$ & 1 & Nos & 332,000 & 332,000 \\
\hline 4 & 500 KVA O/D TRANSFORMER (OIL FILLED) & 1 & each & 720,000 & 720,000 \\
\hline 5 & APFC PANEL (Thyristor Switched) & 1 & No & 459,400 & 459,400 \\
\hline 6 & LT KIOSK 800A TPN 4P 50KA EOD type ACB & 1 & No & 288,000 & 288,000 \\
\hline 7 & $\begin{array}{l}\text { Main LT Panel: I/C: 800A } 4 \text { pole EDO type ACB } \\
\text { (50 KA)-1 No. O/G (400 A TPN MCCB-2 Nos, } \\
250 \text { A-2 Nos, } 125 \text { A-2 Nos, } 100 \text { A-3 Nos) }\end{array}$ & 1 & No & 644,000 & 644,000 \\
\hline 8 & AMF Panel suitable for $750 \mathrm{kVA}$ & 1 & Set & $1,027,500$ & 107,500 \\
\hline
\end{tabular}


reactive current (IL). The two components flowing through the same path will cancel each other, such that if the capacitor bank is sufficiently large and Ic = IL, there will be no reactive current flow in the system upstream of the capacitors. This is indicated in Figure 3 which shows the flow of the reactive components of current only.

In Figure 3: $\mathrm{R}$ is active-power elements of the load, $\mathrm{L}$ is (inductive) reactive-power elements of the load, and $\mathrm{C}$ is (capacitive) reactive-power elements of the power-factor correction equipment (i.e. capacitors).

\section{kVAR required for transformer compensation:}

\begin{tabular}{cc}
\hline Transformer & Required Kva \\
\hline$\leq 315$ kVA T.C & $=5 \%$ of KVA \\
315 kVA to $1000 \mathrm{kVA}$ & $=6 \%$ of KVA \\
$\geq 1000 \mathrm{kVA}$ & $=8 \%$ of KVA \\
\hline
\end{tabular}

\section{Calculation of required capacitor:}

Fixed compensation of the $500 \mathrm{kVA}$ Transformer is $(500 \mathrm{kVA} \times 6 \%)=30 \mathrm{kVAR}$.

Suppose actual P.F is 0.8, required P.F is 0.98 and total connected load is 354 KVA.

$\mathrm{kW}=354 \times 0.8=283.20$. Required capacitance $=283.20 \times$ Multiplying Factor $=283.20 \times 0.547$ (from Table 4 to find Value according to P.F 0.8 to P.F of 0.98$)=155.00 \mathrm{kVAR}$.

Total capacity of the APFC panel = Fixed compensation + Variable compensation i.e., $155 \mathrm{kVAR}+30 \mathrm{kVAR}=$ 185 kVAR (available rating).

The capacity of the APFC panel in Figure 4 shows 155 kVAR capacity rest is fixed compensation. Load Reduction by STWH at $11 \mathrm{kV}$ Electrical Distribution System is represented in Table 5.

\subsection{Impact on Solar Thermal Autoclaves on Electrical Distribution Load at 315 kVA}

Impact on Solar Thermal Autoclaves on Electrical Distribution Load in Institutional Building @60 ${ }^{\circ} \mathrm{C}$ and its cost analysis at $315 \mathrm{kVA}$ level.

\section{Designed capacity of the electrical distribution system is $315 \mathrm{kVA}$ :}

With using the solar water heating system, the hot water output is at $60^{\circ} \mathrm{C}$, but required temperature is around $121^{\circ} \mathrm{C}$. To increase the temperature from $60^{\circ} \mathrm{C}-121^{\circ} \mathrm{C}, 18 \mathrm{~kW} \times 4$ Nos of Electrical Heater are used. The capacity of the Electrical Load is $75 \mathrm{kVA}$ (72 kW at P.F 0.95).

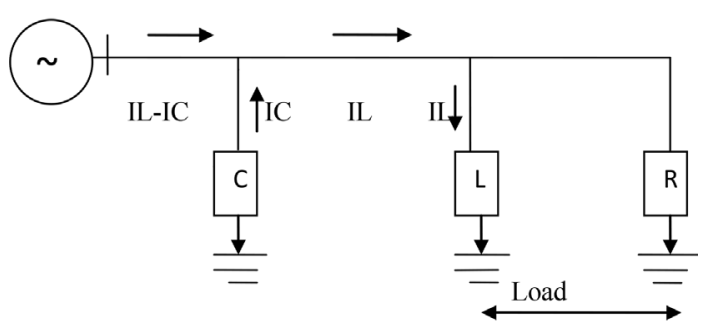

(a)

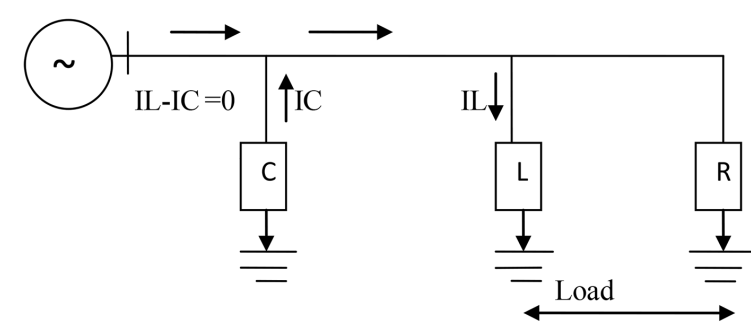

(b)

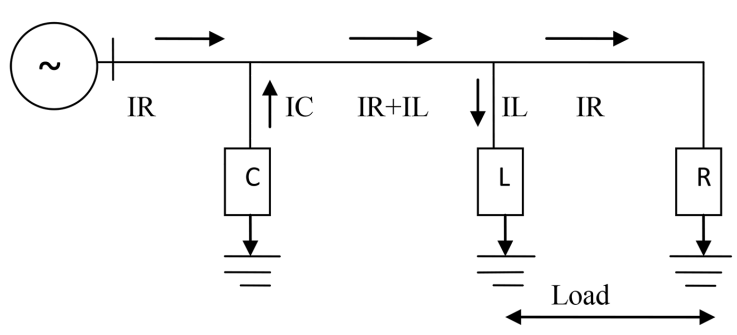

(c)

Figure 3. Showing the essential features of power-factor correction. (a) Reactive current components only flow pattern; (b) When IC = IL, all reactive power is supplied from the capacitor bank; (c) With load current added to case (b). 


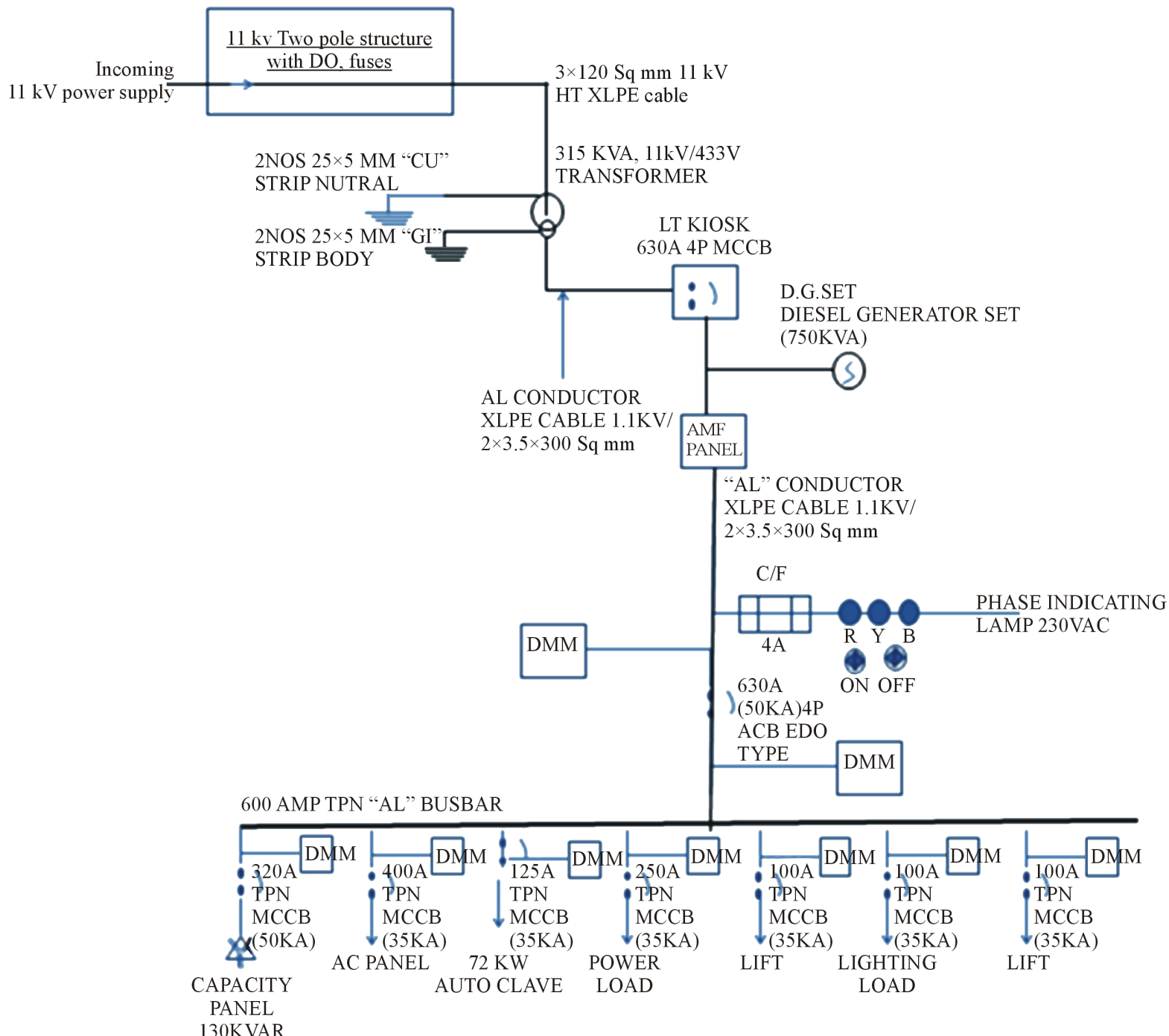

Figure 4. Single line diagram of the electrical distribution system for 315 kVA transformer level.

Table 4. Table for finding the required multiplication factor (P.F from 0.6 to unity) [8].

\begin{tabular}{ccccccccccccc}
\hline & 0.9 & 0.91 & 0.92 & 0.93 & 0.94 & 0.95 & 0.96 & 0.97 & 0.98 & 0.99 & 1 \\
\hline 0.6 & 0.849 & 0.878 & 0.907 & 0.938 & 0.970 & 1.005 & 1.042 & 1.083 & 1.130 & 1.191 & 1.333 \\
0.7 & 0.536 & 0.565 & 0.594 & 0.625 & 0.657 & 0.692 & 0.729 & 0.770 & 0.817 & 0.878 & 1.020 \\
0.8 & 0.266 & 0.294 & 0.324 & 0.355 & 0.387 & 0.421 & 0.458 & 0.499 & 0.547 & 0.608 & 0.750 \\
0.85 & 0.135 & 0.164 & 0.194 & 0.225 & 0.257 & 0.291 & 0.328 & 0.369 & 0.417 & 0.477 & 0.620 \\
0.9 & & 0.029 & 0.058 & 0.089 & 0.121 & 0.156 & 0.193 & 0.234 & 0.281 & 0.342 & 0.484 \\
0.91 & & & 0.030 & 0.060 & 0.093 & 0.127 & 0.164 & 0.205 & 0.253 & 0.313 & 0.456 \\
0.92 & & & & 0.031 & 0.063 & 0.097 & 0.134 & 0.175 & 0.223 & 0.284 & 0.426 \\
0.93 & & & & & 0.032 & 0.067 & 0.104 & 0.145 & 0.192 & 0.253 & 0.395 \\
0.94 & & & & & & 0.034 & 0.071 & 0.112 & 0.160 & 0.220 & 0.363 \\
0.95 & & & & & & & 0.037 & 0.078 & 0.126 & 0.186 & 0.329 \\
\hline
\end{tabular}


The Electrical Distribution system, one of the feeder (250 Amps, TPN MCCB-Power Load feeder) is connected to the domestic water heating load, the total Electrical load of 40 rooms of each $2.5 \mathrm{~kW}$ capacity Electrical heaters are connected,

There for the total capacity of the domestic heating Electrical load is $102 \mathrm{kVA}(100 \mathrm{~kW}$ at 0.98 P.F).

The load reduction is $177 \mathrm{kVA}$ (say $180 \mathrm{kVA}$ ).

Required size of Transformer after load reduction i.e., $500 \mathrm{kVA}-180 \mathrm{kVA}=320 \mathrm{kVA}$

Recommended size of Transformer is $315 \mathrm{kVA}$ and its cost analysis is shown in Table 6.

\subsection{Calculation of Required Capacitor}

Fixed compensation of the $315 \mathrm{kVA}$ Transformer is $(315 \mathrm{kVA} \times 5 \%)=15.75 \mathrm{kVAR}$.

Suppose actual P.F is 0.8 , required P.F is 0.98 and total load is $282 \mathrm{KVA}$.

$\mathrm{kW}=282 \times 0.8=225.60$, Required capacitance $=123.40 \mathrm{kVAR}$.

Total capacity of the APFC panel is $139 \mathrm{kVAR}$ (i.e., fixed compensation + variable compensation). The capacity of the APFC panel in Figure 5 shows 139 kVAR capacity rest is fixed compensation.

\subsection{Impact on Solar Thermal Autoclaves on Electrical Distribution Load in Institutional Building @60 ${ }^{\circ} \mathrm{C}$ and Its Cost Analysis Shown in Table 7 at 250 kVA Level}

Designed capacity of the Electrical Distribution system is $500 \mathrm{kVA}$. With using the solar water heating system with inserts (twisted inserts with Nano fluids), the hot water output is at $90^{\circ} \mathrm{C}$, but required temperature is around $121^{\circ} \mathrm{C}$.

Table 5. Autoclave and its load reduction by STWH systems.

\begin{tabular}{|c|c|c|c|c|c|c|}
\hline Description & $\begin{array}{c}\text { Electrical load } \\
\text { (Auto claves) kVA }\end{array}$ & $\begin{array}{l}\text { Electrical load } \\
\text { (DWHS) kVA }\end{array}$ & $\begin{array}{l}\text { Load reduction } \\
\text { kVA }\end{array}$ & $\begin{array}{l}\text { Recommended } \\
\text { TFR sizes in kVA }\end{array}$ & $@ 60^{\circ} \mathrm{C}$ & $@ 90^{\circ} \mathrm{C}$ \\
\hline $\begin{array}{c}\text { Conventional Electrical } \\
\text { System. }\end{array}$ & 150 & 105 & Nil & 500 & Nil & Nil \\
\hline $\begin{array}{l}\text { Load reduction by STWH's- } \\
\text { with inserts @ } 90^{\circ} \mathrm{C}\end{array}$ & 75 & 105 & 180 & 315 & $\begin{array}{l}\text { Up to } 60^{\circ} \mathrm{C} \text { for } \\
\text { DWHS }\end{array}$ & $\begin{array}{l}\text { With twisted } \\
\text { inserts }\end{array}$ \\
\hline $\begin{array}{l}\text { Load reduction by STWH's } \\
\text { with Nano fluids and twisted } \\
\text { tape inserts@90 } 90^{\circ} \mathrm{C}\end{array}$ & 19 & 105 & 236 & 250 & $\begin{array}{l}\text { Up to } 60^{\circ} \mathrm{C} \text { for } \\
\text { DWHS }\end{array}$ & $\begin{array}{l}\text { With inserts and } \\
\text { Nano fluids }\end{array}$ \\
\hline
\end{tabular}

Table 6. Cost analysis of electrical distribution systems at 315 kVA TFR level.

\begin{tabular}{|c|c|c|c|c|c|}
\hline S No. & Description & Qty & UoM & Rate (Rs) & Amount (Rs) for $315 \mathrm{kVA}$ \\
\hline 1 & $\begin{array}{l}\text { HT Cable: Supply of } 3 \text { Core } 11 \text { KV } 120 \text { Sqmm HT } \\
\text { XLPE (E) armoured Cable. }\end{array}$ & 50 & Mtr & 1100 & 55,000 \\
\hline 2 & $\begin{array}{l}\text { LT cables: Supply of } 400 \text { Sqmm } 3.5 \text { Core XLPE insulated, } \\
\text { 1100V grade armoured aluminium cable. }\end{array}$ & 100 & Mtr & 1800 & 180,000 \\
\hline 3 & HT Metering Panel (11kV) & 1 & No & 332,000 & 332,000 \\
\hline 4 & 315 kVA O/D Transformer (Oil Filled) & 1 & each & 600,000 & 600,000 \\
\hline 5 & APFC PANEL(Thyristor Switched) 100 kVAR & 1 & No & 368,000 & 368,000 \\
\hline 6 & LT KIOSK 630A TPN 4P 50KA EOD type ACB & 1 & Set & 260,000 & 260,000 \\
\hline 7 & $\begin{array}{c}\text { Main LT Panel: I/C: (800A } 4 \text { pole EDO type ACB-50 KA-1 } \\
\text { No) and Outgoings (400 A TPN MCCB (35 KA)-2 Nos, } \\
\text { 250 A-2 Nos, } 200 \text { A-2 Nos, } 100 \text { A-2 Nos. }\end{array}$ & 1 & Set & 540,500 & 540,500 \\
\hline 8 & AMF Panel suitable for $500 \mathrm{kVA}$ & 1 & Set & 860,000 & 860,000 \\
\hline & Total & & & & $3,195,500$ \\
\hline
\end{tabular}


To increase the temperature from $90^{\circ} \mathrm{C}-121^{\circ} \mathrm{C}, 18 \mathrm{~kW} \times 1$ No of Electrical Heater are used. The capacity of the Electrical Load is $19 \mathrm{kVA}(18 \mathrm{~kW}$ at P.F 0.95).

The load reduction is $126 \mathrm{~kW}(133 \mathrm{kVA}, \mathrm{P} . \mathrm{F}$ as 0.95$)$.

The Electrical Distribution system, one of the feeder (250 Amps, TPN MCCB-Power Load feeder) is connected to the domestic water heating load, the total Electrical load of 40 rooms of each $2.5 \mathrm{~kW}$ capacity Electrical heaters are connected,

There for the total capacity of the domestic heating Electrical load $=102 \mathrm{kVA}$ (100 kW at 0.98 P.F). Load reduction is $235 \mathrm{kVA}$.

The required size of Transformer after load reduction i.e., $500 \mathrm{kVA}-235 \mathrm{kVA}=265 \mathrm{kVA}$. So, recommended size of Transformer is $250 \mathrm{kVA}$, the cost analysis of the system is represents in Table 8 .

\section{Calculation of required capacitor:}

Fixed compensation of the $500 \mathrm{kVA}$ Transformer is $(250 \mathrm{kVA} \times 5 \%)=12.5 \mathrm{kVAR}$.

Actual P.F is 0.8 , required P.F is 0.98 and total load is $210 \mathrm{KVA}$.

$\mathrm{kW}=210 \times 0.8=168$,

Required capacitor $=\mathrm{kW} \times$ Multiplying Factor $=168 \times$ Multiplying Factor $=168 \times 0.547$ (from table to find Value according to P.F 0.8 to P.F of 0.98) $=92 \mathrm{kVAR}$.

Total capacity of the APFC panel is $105 \mathrm{kVAR}$ (i.e., fixed compensation + variable compensation).

The capacity of the APFC panel in Figure 5 shows 80 kVAR capacity rest is fixed compensation.

\subsection{Methodology}

In the first stage of the study, the hot water temperature is enhanced to $90^{\circ} \mathrm{C}$ by using inserts into the solar flat plate collector fins. The enhanced water is fed to the Autoclaves for generation of the steam at $121^{\circ} \mathrm{C}$. Information such as current (Amps), voltage (Voltage) and power $(\mathrm{kW})$ was collected directly from the nameplate affixed on the Autoclave.

Table 7. Impact of solar thermal systems on electrical distribution system at $90^{\circ} \mathrm{C}$.

\begin{tabular}{ccccccccc}
\hline \multicolumn{1}{c}{ Description } & $\begin{array}{c}\text { No of } \\
\text { Geysers }\end{array}$ & $\mathrm{kW}$ & $\begin{array}{c}\text { Units/day/ } \\
\text { geyser }\end{array}$ & No. of units & $\begin{array}{c}\text { Unit rate } \\
\text { (Rs) }\end{array}$ & $\begin{array}{c}\text { Cost/day } \\
\text { (Rs) }\end{array}$ & $\begin{array}{c}\text { Cost/month } \\
\text { (Rs) }\end{array}$ & $\begin{array}{c}\text { Cost/annum } \\
\text { (Rs) }\end{array}$ \\
\hline Electric Geyser (2.5 kW) & 40 & 100 & 11 & 440 & 7.00 & 3080 & 92,400 & $1,108,800$ \\
\multicolumn{1}{c}{ SWHS } & Nil & Nil & 08 FPC & Nil & Nil & Nil & Nil & Nil \\
\hline
\end{tabular}

Table 8. Cost analysis of electrical distribution systems at $250 \mathrm{kVA}$ TFR level.

\begin{tabular}{|c|c|c|c|c|c|}
\hline S No. & Description & Qty & UoM & Rate (Rs) & $\begin{array}{l}\text { Amount (Rs) at } \\
250 \mathrm{kVA} \text { level }\end{array}$ \\
\hline 1 & $\begin{array}{l}\text { HT Cable: Supply of } 11 \text { kV, 3c × } 120 \text { Sqmm HT } \\
\text { XLPE armoured Cable. }\end{array}$ & 50 & Mtr & 1100 & 55,000 \\
\hline 2 & $\begin{array}{l}\text { LT cables: Supply of } 400 \text { Sqmm } 3.5 \text { Core XLPE insulated, } \\
\text { 1100V grade armoured aluminium cable. }\end{array}$ & 100 & Mtr & 1800 & 180,000 \\
\hline 3 & HT Metering Panel $11 \mathrm{kV}$ & 1 & No & 332000 & 332,000 \\
\hline 4 & 250 kVA O/D Transformer (Oil Filled) & 1 & each & 520000 & 520,000 \\
\hline 5 & APFC Panel (Thyristor Switched) & No & 1 & 294400 & 294,400 \\
\hline 6 & LT KIOSK 800A TPN 4P 50KA EOD type ACB & 1 & Set & 260000 & 260,000 \\
\hline 7 & $\begin{array}{l}\text { Main LT Panel: I/C (800A } 4 \text { pole EDO type ACB-50 kA-1 } \\
\text { No, Outgoing (400 A TPN MCCB-35 kA-1 Nos, } \\
\text { 250 A-3 Nos, } 100 \text { A-3 Nos. }\end{array}$ & 1 & Set & 455,000 & 455,000 \\
\hline 8 & AMF Panel suitable for $320 \mathrm{kVA}$ & 1 & Set & 660,000 & 660,000 \\
\hline \multicolumn{5}{|c|}{ Total } & $2,756,400$ \\
\hline
\end{tabular}




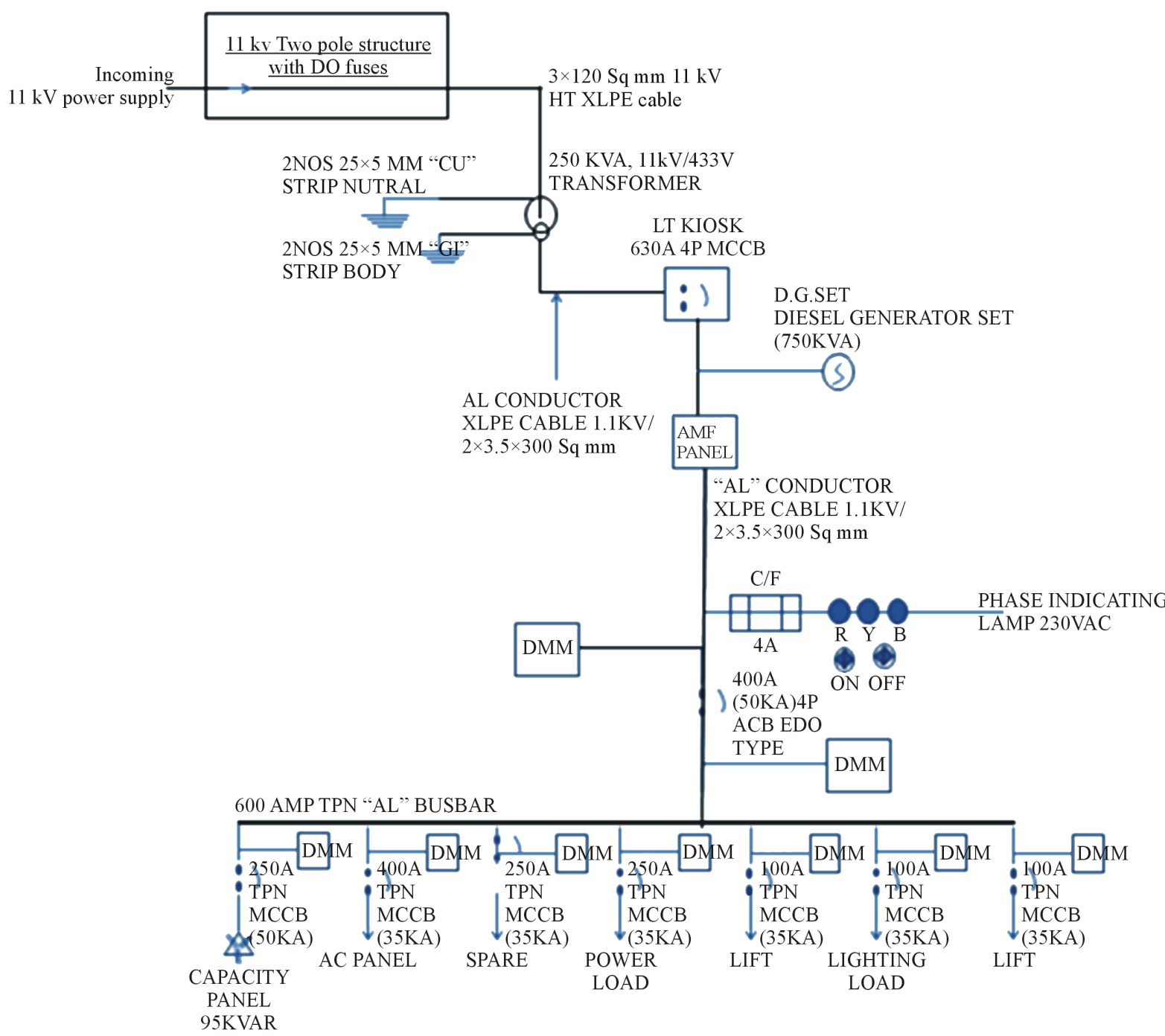

Figure 5. Single Line Diagram (SLD) of the electrical distribution system for $250 \mathrm{kVA}$ transformer level.

After measuring the power consumption of the Autoclaves without solar hot water, the capacity of the Transformer was estimated. Then by using the solar hot water at $90^{\circ} \mathrm{C}$ was estimated. The cost savings of the system was calculated with Autoclave Electrical Heaters and without Electrical heaters for $60^{\circ} \mathrm{C}$ and $90^{\circ} \mathrm{C}$. For the equipment which was tested, the weekly power consumption (kWh/week) can be obtained using the same equation. But instead of using the nameplate power rating, the actual measured power rating was used. According to the calculations, the cost of the Transformer changes from rating to rating. In this context, it is important to note that this rate of cost of higher capacity Transformer and its associated feeders is less than smaller capacities and also considerable Electrical Energy savings are noted with and without Solar Hot water systems.

\section{Conclusions}

The electrical energy consumption and its cost analysis have been calculated for systems and observed that there is a considerable savings by using the solar hot water at $90^{\circ} \mathrm{C}$. The use of $\mathrm{Al}_{2} \mathrm{O}_{3}$ nanoparticles as the dispersed phase in water can significantly enhance the convective heat transfer in the transition flow, and the enhancement increases with increase in particle concentration and further can be increased by using the different types of inserts. The temperature of the outlet get at $90^{\circ} \mathrm{C}$ and the same has been connected to the Autoclave.

For laboratory equipment sterilisation, commonly autoclaves are used. These equipments are consumes highest electrical power consumption in terms of $\mathrm{kWh}$. The use of solar energy, the feed water to the autoclave is fed 
at $90^{\circ} \mathrm{C}$ by using different methods to enhance the temperature. Average weekly power consumption, capacities and cost of operation were analysed. By using the enhanced methods, the cost of the electrical distribution network and its capacities are optimised at feeder level.

\section{References}

[1] Paull, L., Li, H. and Chang, L.C. (2010) A Novel Domestic Electric Water Heater Model for a Multi-Objective Demand Side Management Program. Electric Power Systems Research, 80, 1446-1451. http://dx.doi.org/10.1016/j.epsr.2010.06.013

[2] Knudsen, S. (2002) Consumers' Influence on the Thermal Performance of Small SDHW Systems-Theoretical Investigations. Solar Energy, 73, 33-42. http://dx.doi.org/10.1016/S0038-092X(02)00018-X

[3] Kalogirou, S.A. (2004) Solar Thermal Collectors and Applications. Progress in Energy and Combustion Science, 30, 231-295. http://dx.doi.org/10.1016/j.pecs.2004.02.001

[4] Zhang, R., Zhu, H., Wen, H. and Li, M. (1993) Performance Analysis of a Solar Glass Tube Collector. Renewable Energy, 3, 877-883.

[5] Swanson, B.S. and Fletcher, J.H. (2008) Analysis of Solar Thermal Water Heaters on Peak Demand. Proceedings of ECTC 2008, 2008 ASME Technical Conference, 3-4 October 2008.

[6] http://www.energysavers.gov/tips/water heating.cfm

[7] Taylor, Z.T., Gowri, K. and Katipamula, S (2008) GridLAB-D Technical Support Document: Residential End-Use Module Version 1.0.

[8] https://electricalnotes.wordpress.com/2011/03/20/automatic-power-factor-correction 